\title{
Role of Risk Mitigation in Project Completion; A Survey of Constituency Development Fund Secondary Projects in Mwea Constituency, Kenya
}

\author{
Peter Gitau ${ }^{1}$, Wanjugu Wachira², David Gichuhi ${ }^{3}$ \\ ${ }^{12}$ Faculty of Social Sciences, St Pauls University, Kenya \\ ${ }^{3}$ School of Business, Karatina University, Kenya \\ ${ }^{1}$ Corresponding Author: njupeter2@gmail.com, +254-722-715-068 \\ DOI: 10.29322/IJSRP.11.08.2021.p11677 \\ http://dx.doi.org/10.29322/IJSRP.11.08.2021.p11677
}

\begin{abstract}
Despite allocation of huge Constituency Development Fund (CDF) amounts to the education sector, many projects had stalled and others failed to kick off despite availability of funds. This study therefore sought to examine how risk mitigation affects the completion of CDF secondary school projects in Mwea Constituency. Specifically, the study sought to assess risk mitigation practices, determine project completion and establish the effect of risk mitigation on the completion of CDF secondary school projects in Mwea Constituency. The current study employed a descriptive survey design. This study targeted CDF public secondary school projects in Mwea Constituency, Kenya. Project management committee members were the respondents in the study. As of February, 2020, there are 48 CDF public secondary school projects in the constituency. The school's principal, a community member and 1 representative from the school board were purposively selected. In addition, the CDF fund manager and the 8 members of the CDF committee were selected. The study therefore had a sample size of 153 respondents. A questionnaire was used to collect data from the respondents in the study. Descriptive statistics comprising frequencies, percentages were employed to analyze data. Correlation analysis was employed to find out the direction and magnitude between the independent variables and project completion. Statistical Package for Sciences (SPSS) Version 24 for Windows was used. The study found that the rate of project completion was quite low. Analysis of data showed that there was very poor risk mitigation. Results showed that there was a strong positive correlation $(\mathrm{r}=0.742, \mathrm{n}=137, \mathrm{p}=0.000)$ between risk mitigation and project completion. The study therefore concluded that risk mitigation has a strong positive and significant effect on the completion of CDF secondary school projects in Mwea Constituency. Therefore, CDF projects ought to have a risk management plan which includes controls in place.
\end{abstract}

Keywords: Risk mitigation, risk management, project completion, CDF projects

\section{INTRODUCTION}

Projects are temporary endeavors which lead to the creation of unique services, products, or results (Musembi, Guyo, Kyalo \& Mbuthia, 2018). A project can be defined as a temporary endeavor undertaken by people who work cooperatively together to create a unique product or service within an established period and within an established budget to produce identifiable deliverables (Project Management Institute, 2010). Completion of projects within schedule is a major contribution towards the competitive edge in organizations. This is based on the realization that the achievement of the targeted objectives is determined by the ability to deliver the targeted output within the stipulated time (Kariungi, 2014). Project management cycle involves the series of activities that is followed through stages of project completion to achieve its goal. Generally, the successful measure of a project is defined by completing it within specified cost, time, scope and quality (Ogutu \& Muturi, 2017). 
Project completion is affected by many factors. The most popular critical success factors accepted by research community are-project mission, top management support, project schedule/plan, client consultation, personnel, technology to support the project, client acceptance, monitoring and feedback, channels of communication, troubleshooting expertise (Babu\&Sudhakar,2015). Haried and Ramamurthy (2009) believed that reasons for not achieving project success can be attributed to poor project management skills in aspects such as project planning, financial planning and hands-off approach by key project holders. Upadhyay (2016) identified critical factors required for successful completion of projects. Factors included effective planning and scheduling by a clear understanding of project scope and specifications, detailed preparation of the contract, design documents, and drawings before starting the work at the site, owner's commitment to pay the contractor on time and clear definition of responsibilities of each party. Other factors included availability of labors and equipment necessary for the project, on time delivery of required materials, qualified contractors, subcontractors, project manager and site engineers.

According to Kyalo and Muturi (2015), one of the major problems faced by projects is on timely task completion which is the ultimate goal in any project. Globally, timely completion of projects is below 50\%. Although many projects have been initiated across the SubSahara very few see successful completion. According to Deloitte (2018), approximately only $20 \%$ of projects (from inception) in Africa reach financial closure and are able to move to execution. In Kenya, majority of projects are never completed and most construction projects are completed with cost overruns, out of quality, beyond completion time and out of scope (Ogutu \& Muturi, 2017). The ministry of public works which is mandated to provide and maintain projects for the public sector (2012) gives $38.60 \%$ as the average percentage project completion rate for 2005-2011. Cost and time overruns have been identified as playing a significant role in the abandonment of projects and in project failure in Kenya. Approximately $48 \%$ of projects report a cost overrun and $87 \%$ of projects have a time overrun (Deloitte, 2017).

Projects can be extremely complex and fraught with uncertainty. Risk and uncertainty can potentially have damaging consequences for the projects (Banaitiene \& Banaitis, 2012). Risk management refers to the practice of identifying potential risks in advance, analyzing them and taking precautionary steps to reduce/curb the risk (Nyaga, 2014). Project risk management is therefore the process of identifying, analyzing and then responding to any risk that arises over the life cycle of a project to help the project remain on track and meet its goal. The objective of project risk management is to increase the likelihood and impact of positive events and decrease the likelihood and impact of negative events on the project. Abdul-Rahman, Wang and Sheik Mohamad (2015) indicates that delays, cost overruns, and reduction of quality of projects are the common negative effects of risk inherent to construction projects. The risk mitigation strategy plays a vital role to keep the project on track for which identification of potential risks is a must (Ahmed, 2017).

Risk is the Possibility of suffering loss and the impact on the involved parties. According to APM (2006), all projects are inherently risky because they are unique, constrained, complex, based on assumptions, and performed by people. Projects also tend to exceed planned timelines and budgets. One reason may be that potential project risks are insufficiently reflected in anticipations of project success (Fabricius \& Büttgen, 2015). Risk associated with a project it is termed project risk, which often reflects the project's unfavorable state. As a result, project risk management methods must be built into the management of projects and should be used throughout the project lifecycle

Project risk management (PRM) is therefore art and science of identifying, analyzing, and responding to risk throughout the life of a project and in the best interests of meeting project objectives (Pimchangthong \& Boonjing, 2017). It is a process with the intention to identify, analyzes, and manage events and situations that potentially form a threat to the success of the project. The PRM process consists of a limited number of activities. The typical activities of PRM are: risk planning, identification, analysis, and control (Bakker, 2009).

Given the importance of project risk management in project management functioning, the efficiency of risk management is expected to significantly influence project performance (Kinyua, Ogollah \& Mburu, 2015). Previous studies in the project management in information technology and construction have shown that the application of risk management has affected project performance in terms of efficiency, performance improvement and productivity enhancement (Al Mihrat \& Irtemeh , 2017).According to Teller (2013), previous research has found supporting evidence of a positive relationship between project risk management and project success, but literature on how risk management is applied to and integrated with project portfolios has been scarce.

This publication is licensed under Creative Commons Attribution CC BY.

http://dx.doi.org/10.29322/IJSRP.11.08.2021.p11677

WWW.ijsrp.org 
The Constituency Development Fund was introduced in Kenya in 2003 with the passage of the CDF Act 2003 by the 9th Parliament of Kenya. It aims at ensuring a portion of the Government Annual Revenue is earmarked for constituencies to finance development projects qualified on a priority basis arrived at by members of a Constituency (Yatich \& Sakataka, 2016). The National Government Constituencies Development Fund (NG-CDF) Act 2015 replaced the Constituencies Development Fund (CDF) Act 2013 with effect from 19th February 2016. Under this Act, 2.5\% of the total government revenue is allocated and shared among all the constituencies. $\mathrm{CDF}$ aims at decentralizing resources to constituencies for equitable development. It was designed to support equitable constituencylevel and grass-root development (Nakhumicha \& Macharia, 2017).

Mwea Constituency is an example of areas where a large proportion of CDF funds have been allocated to education especially in secondary schools. For example, in the 2014/2015 financial year, Mwea CDF spent 37.7 million shillings in the education sector which represented $77.1 \%$ of their total expenditure (Republic of Kenya, 2016). However despite allocation of huge amounts to this sector, many projects have stalled and others failed to kick off despite availability of funds. This is mainly seen in construction projects such as building class rooms and structures in secondary school premises. The number of incomplete CDF secondary school projects in Mwea Constituency is higher than that of neighboring constituencies such as Gichugu, Ndia and Kirinyaga Central. The high number of incomplete projects suggests the existence of underlying factors which have not been identified. This study therefore sought to examine the effect of risk mitigation on the completion of CDF secondary school projects in Mwea Constituency. The objectives of the study were to: assess risk mitigation practices among CDF secondary school projects in Mwea Constituency, determine project completion among CDF secondary school projects in Mwea Constituency and establish the effect of risk mitigation on the completion of CDF secondary school projects in Mwea Constituency

\section{METHODOLOGY}

The current study employed a descriptive survey design. In this study, the researcher investigated factors affecting the completion of CDF public secondary school projects by studying team leadership, public participation, project management skills and risk mitigation. This design was ideal because it enabled the researcher conduct the study using few resources and in a short time. The current study was conducted in Mwea Constituency. Mwea Constituency is one of the 4 constituencies in Kirinyaga County which is located in the central part of Kenya. It covers an area of about $51 \mathrm{~km} 2$ with an estimated population of 190, 516.

This study targeted CDF public secondary school projects in Mwea Constituency, Kenya. As of February, 2020, there are 48 CDF public secondary school projects in the constituency (Mwea Constituency CDF, 2020). Project management committee members were the respondents in the study. The project management committee for each CDF secondary school project comprised 12 persons which includes the $8 \mathrm{CDF}$ committee members, 1 fund manager, the school's principal, a community member and 1 representative from the school board. For the purposes of this study, purposive sampling was used to come up with a sample. All 48 CDF projects were therefore considered for this study. The researcher then purposively selected the school's principal, a community member and 1 representative from the school board. In addition, the CDF fund manager and the 8 members of the CDF committee were selected. The study therefore had a sample size of 153 respondents comprising the CDF fund manager, 8 CDF committee members, 48 public secondary school principals, 48 community members and 48 representatives from the school board.

A questionnaire was used to collect data from the respondents in the study. The questionnaire was structured and will be selfadministered by the respondents. To establish validity of the instrument, questions in the study was developed from the indicators shown in the conceptual framework. To establish reliability, a pretest was conducted. The pretest was conducted in 5 CDF public secondary school projects in Ndia Constituency. Data collected in the pretest was subjected to reliability analysis using Statistical Package for Sciences (SPSS) Version 24 for Windows. Spearman rank correlation was used to measure reliability whereby a coefficient of 0.8 and above was accepted. Descriptive statistics comprising frequencies, percentages were employed to analyze data. Correlation analysis was also used. Tables and charts were used to present findings. 


\section{RESULTS AND DISCUSSION}

A total of 146 questionnaires were received. This constitutes a 95.4\% response rate.

\section{Socio-Demographic Characteristics of Respondents}

Results indicate that $54.1 \%$ of the respondents were male while $45.9 \%$ were female. Results in Table 1 indicate that $27.8 \%$ of the respondents were aged between 31 and 40 years while 26.4\% were aged between 41 and 50 years. The results show that $24.3 \%$ of the respondents were aged over 51 years while $21.5 \%$ were aged between 21 and 30 years. The results therefore show that $50.1 \%$ of the respondents were over the age of 40 years. The study findings that all the respondents in the study had acquired higher education whereby $42.4 \%$ of them had a diploma, $17.4 \%$ had a bachelor's degree while $16 \%$ had a certificate as shown in Table 1 . Results show that $32.9 \%$ of the respondents were project managers, $28.8 \%$ were technical experts while $15.8 \%$ were monitoring evaluation experts. Results show that $34.2 \%$ of the respondents had between 11 and 15 years of experience of project management while $31.5 \%$ had between 6 and 10 experience. Those respondents who had between 1 and 5 years of experience accounted for $28.1 \%$.

\section{Table 1Socio-Demographic Characteristics of Respondents}

\begin{tabular}{llll}
\hline Demographic & Category & Frequency N=146 & Percent \\
\hline Gender & Male & 79 & 54.1 \\
Age & Female & 67 & 45.9 \\
& $21-30$ & 31 & 21.2 \\
& $31-40$ & 41 & 28.1 \\
Level of education & $41-50$ & 39 & 26.7 \\
& $>51$ & 35 & 24.0 \\
& Certificate & 23 & 16.0 \\
& Diploma & 61 & 42.4 \\
Respondents' Role in Project & Higher diploma & 14 & 9.7 \\
& Bachelor's degree & 25 & 17.4 \\
& Post graduate degree & 21 & 14.6 \\
& Project manager & 48 & 32.9 \\
& Technical expert & 42 & 28.8 \\
Respondents' Experience in Project Management & $1-5$ & 13.7 \\
& Community liaison & 20 & 8.9 \\
& Financial manger & 13 & 15.8 \\
& Monitoring and evaluation & 23 & 28.1 \\
& $1-5-10$ & 41 & 31.5 \\
& $11-15$ & 46 & 34.2 \\
& $16-20$ & 50 & 2.7 \\
& $>21$ & 4 & 3.5 \\
\hline
\end{tabular}

\section{Project Completion}

Results in Table 2 show that $47.6 \%$ of the respondents indicated that their project was completed in the stipulated time. Results show that only $30.7 \%$ agreed that their project was completed within the initial budget. Similarly, only $25.2 \%$ indicated that the complete project was of the agreed quality. The results show that $31.5 \%$ agreed that the complete project satisfied the client's needs. Majority (66.5\%) disagreed that the project stalled. These results indicate that the rate of project completion of CDF public secondary school projects in Mwea Constituency, Kenya is quite low. These results indicate that the rate of project completion of CDF public secondary school projects in Mwea Constituency, Kenya is quite low. This result is in agreement with findings of Kyalo and Muturi (2015) that one of the major problems faced by projects is on timely task completion which is the ultimate goal in any project. The finding is also in agreement with findings of Ogutu and Muturi (2017) who found that majority of projects are never completed and most construction This publication is licensed under Creative Commons Attribution CC BY. 
projects are completed with cost overruns, out of quality, beyond completion time and out of scope However, the rate of completion of CDF public secondary school projects in Mwea Constituency (47.6\%) is higher than the average (38.6\%) rate of completion of public projects according to the Ministry of Public Works (2018). It is also higher than the 20\% reported by Deloitte (2018), for African projects.

\section{Table 2 Project Completion}

\begin{tabular}{llllll}
\hline & 1 & 2 & 3 & 4 & 5 \\
\hline The project was completed in the stipulated time & $15.4 \%$ & $32.2 \%$ & $30.1 \%$ & $16.8 \%$ & $5.6 \%$ \\
The project was completed within the initial budget & $10.7 \%$ & $20 \%$ & $30 \%$ & $31.4 \%$ & $7.9 \%$ \\
The complete project was of the agreed quality & $5.6 \%$ & $19.6 \%$ & $37.8 \%$ & $30.1 \%$ & $7 \%$ \\
The complete project satisfied the client's needs & $7 \%$ & $24.5 \%$ & $23.8 \%$ & $32.2 \%$ & $12.6 \%$ \\
The project stalled & $8.4 \%$ & $4.2 \%$ & $21 \%$ & $24.5 \%$ & $42 \%$ \\
\hline
\end{tabular}

\section{Risk Mitigation Practices}

Results in Table 4.11 show that $36.6 \%$ of the respondents disagreed that risks in the study were identified however $35.8 \%$ agreed. Results show that $40 \%$ disagreed that project risks were analyzed and categorized. Most (52.2\%) disagreed that the project adopted a risk management plan. Most (54\%) disagreed that risk management plan included a response plan. Similarly, 50\% of the respondents disagreed that controls were put in place to avoid various risks. In addition, most (57.1\%) disagreed that risks were actively monitored as the project proceeded. These results therefore show a lack of risk mitigation in completion of CDF secondary school projects in Mwea Constituency. Abdul-Rhaman et al. (2015) also found that the implementation of risk management process in Malaysian construction industry is still at a low level, mainly due to the fact that most of the construction employees involved in risk management are not fully aware of the available risk management techniques that can be applied in construction projects. Gitau (2015) found that the process of risk management was not adequate and no measures were put in place to mitigate the risks. The results are similar to those of Amoah and Pretorius (2019) who found that small construction companies with respect to the case study company do not have a specific laid down risk management processes that project team are made to go through before and during the execution of their projects. However, the results differ from those of Musyoka (2012) who found that risk management practices have been widely applied in projects which were considered to be complex as these projects attracted a lot of public attention because of substantial impacts on communities, economy, environment, and budgets

Table 3 Risk Mitigation Practices

\begin{tabular}{llllll}
\hline & 1 & 2 & 3 & 4 & 5 \\
\hline $\begin{array}{l}\text { Risks in the project were identified } \\
\text { Project risks were analyzed and categorized from the most important }\end{array}$ & $7.6 \%$ & $28.2 \%$ & $27.5 \%$ & $28.2 \%$ & $8.4 \%$ \\
to the least important & & & & & \\
The project adopted a risk management plan & $5 \%$ & $19.3 \%$ & $23.6 \%$ & $37.9 \%$ & $14.3 \%$ \\
The risk management plan included a response plan & $1.5 \%$ & $25.5 \%$ & $19 \%$ & $41.6 \%$ & $12.4 \%$ \\
Controls were put in place to avoid various risks & $3.6 \%$ & $20.7 \%$ & $25.7 \%$ & $42.1 \%$ & $7.9 \%$ \\
Risks are actively monitored as the project proceeds & $2.1 \%$ & $15 \%$ & $25.7 \%$ & $47.1 \%$ & $10 \%$ \\
\hline
\end{tabular}

\section{Effect of Risk Mitigation on Project Completion}

Risk mitigation was correlated with project completion. Results show that there was a strong positive correlation ( $\mathrm{r}=0.742, \mathrm{n}=137$, $\mathrm{p}=0.000$ ) between risk mitigation and project completion. This indicates that risk mitigation affects project completion to a very large

This publication is licensed under Creative Commons Attribution CC BY.

http://dx.doi.org/10.29322/IJSRP.11.08.2021.p11677

www.ijsrp.org 
extent. This indicates that risk mitigation affects project completion to a very large extent. This is in agreement with findings of Lugusa (2016) whose analysis showed that project risk management had the strongest positive on performance of bank financed projects. The finding is in agreement with findings of Kinyua et al. (2015) who established that there existed a positive relationship between risk management strategies affecting project performance and ICT project performance for SMEs in Kenya and were statistically significant at 0.05 level. De Bakker et al. (2010) established that risk management contributes to project success, because the stakeholders are aware of the fact that there are risks, on the basis of which they adjust their expectations and behaviour accordingly. The finding is in agreement with results of DeCarvalho and Junior (2014) demonstrate that adopting risk management practices has a significant positive impact on project success. They also show a positive impact from the presence of a risk manager on project success. Kishk and Ukaga (2008) found that the cause of the projects failure can be directly related to the extent of risk management undertaken. Besides, the level of risk management process undertaken during a project impacts directly on the success or otherwise of the project. The finding is also in agreement with Girardi et al. (2017) who suggested that the impact of risk factors in the performance of projects depends on risk management intensity and on the skills of risk managers, but it does not vary with project complexity. However, Amoah and Pretorius (2019) found no conclusive evidence regarding the impact of risk management on project performance as a significant number of projects done were able to meet a successful project performance indicators even though risk management exercises were not done.

\section{Table 4 Correlation between Risk Mitigation and Project Completion}

\begin{tabular}{llllll}
\hline & & Value & Asymp. Std. Error ${ }^{\mathrm{a}}$ & Approx. T & Approx. Sig. \\
\hline Interval by Interval & Pearson's R & .742 & .036 & 12.855 & $.000^{\mathrm{c}}$ \\
Ordinal by Ordinal & Spearman Correlation & .731 & .040 & 12.437 & $.000^{\mathrm{c}}$ \\
N of Valid Cases & & 137 & & & \\
\hline
\end{tabular}

\section{CONCLUSION}

The study concludes that the rate of project completion of CDF public secondary school projects in Mwea Constituency, Kenya is low. The study concludes that CDF public secondary school projects have poor risk mitigation practices. Risk mitigation has a strong positive and significant effect on the completion of CDF secondary school projects in Mwea Constituency. The study found that the vast majority of projects had poor risk mitigation. Risks in the majority of projects were not identified, analyzed or categorized. Majority of projects did not have a risk management plan. There were no controls put in place to avoid various risks in majority of projects. Risks were also not actively monitored as the project proceeds. This reduced project completion. Projects which had achieved completion were found to have the highest risk mitigation measures.

The National Government Constituencies Development Fund therefore ought to make it mandatory for project management teams in CDF projects to have a risk management plan which includes controls in place. This is because risk management was found to the most deficient and most important factor in project completion of all the factors under investigation in this study. This study found that risk mitigation was poorly conducted in CDF secondary school projects in Mwea Constituency. This warrants more investigation as to why these projects are struggling to put in place risk mitigation measures. A study should therefore be done into risk mitigation practices and challenges in CDF projects.

\section{REFERENCES}

Abdul-Rahman, H., Wang, C., \& Sheik Mohamad, F. (2015). Implementation of Risk Management in Malaysian Construction Industry: Case Studies. Journal of Construction Engineering, 2015, 1-6. https://doi.org/10.1155/2015/192742

Ahmed, R. (2017). Impact of Project Manager's Intellectual Competencies on Project Success. SSRN Electronic Journal. https://doi.org/10.2139/ssrn.3044362 
Amoah, C., \& Pretorius, L. (2019). Evaluation of the impact of risk management on project performance in small construction firms in South Africa: The case study of construction systems. Journal of Engineering, Design and Technology. https://doi.org/10.1108/JEDT-06-2018-0098

Babu, S. S., \&Sudhakar, D. (2015). Critical success factors influencing performance of construction projects. International Journal of Innovative Research in Science, Engineering and Technology, 4(5), 3285-3292.

Banaitiene, N. and Banaitis, A. (2012) Risk Management in Construction Projects. In: Risk Management-Current Issues and Challenges, InTech, Vilnius. https://doi.org/10.5772/51460

De Carvalho, M. M., \&Rabechini Junior, R. (2015, January 17). Impact of risk management on project performance: The importance of soft skills. International Journal of Production Research. Taylor and Francis Ltd. https://doi.org/10.1080/00207543.2014.919423

Girardi, L. R., Junior, R. R., \&Moutinho, J. D. A. (2018). Characterization of risk factor management in infrastructure projects. Gestao e Producao, 25(1), 30-43. https://doi.org/10.1590/0104-530X3011-16

Haried, P., \& Ramamurthy, K. (2009). Evaluating the Success in International Sourcing of Information Technology Projects: The Need for a Relational Client-Vendor Approach. Project Management Journal, 40(3), 56-71. https://doi.org/10.1002/pmj.20113

Kariungi SM. 2014. Determinants of Timely Completion of Projects in Kenya: A Case of Kenya Power and Lighting Company, Thika ABC Journal of Advanced Research, 3, 9-19.

Kinyua, E., Ogollah, K., \&Mburu, D. K. (2015). Effect of risk management strategies on project performance of small and medium information communication technology enterprises in Nairobi, Kenya. International Journal of Economics, Commerce and Management, 3(2), 1-30.

Kishk, M., \&Ukaga, C. (2008). The impact of effective risk management on project success.

Kyalo, K. J., \&Muturi, W. (2015). Factors Affecting Completion of Government Funded Projects, a Survey of Projects in the Ministry of Water and Environment. Journal of Economics and Sustainable Development www.iiste.org ISSN (Vol. 6). Online. Retrieved from www.iiste.org

Lugusa, S. I. (2016). Influence of Project Management Skills on Performance of Bank Financed Projects in Kenya: A Case of Commercial Banks Projects Strategic Journal of Business \&Change Management. Retrieved January 29, 2020, from http://strategicjournals.com/index.php/journal/article/view/272

Musembi, A. K. K., Guyo, W., Kyalo, D. N. \&Mbuthia, A. (2018). Effect of employees' soft skills on performance of public energy sector projects in Kenya. International Academic Journal of Human Resource and Business Administration, 3(2), 1-13

Nakhumicha, W. S., \&Macharia, D. (2017). Factors influencing completion of development projects in secondary schools: A case of CDF projects in Imenti North Sub County in Meru, Kenya. International Academic Journal of Information Sciences and Project Management, 2(1), 390-400.

Nyaga, K. G. (2014). Role of project management skills on performance of construction projects: a case of selected construction firms in Mombasa county, Kenya (Doctoral dissertation, University of Nairobi).

Ogutu, B. O., \&Muturi, W. (2017). Factors influencing successful completion of road construction projects in Kenya: The Case of Kisumu County. International Journal of Economics, Commerce and Management, 5(6), 657-698.

Upadhyay, A. (2016). A case study on schedule delay in construction projects in Gwalior. International Research Journal of Engineering and Technology (IRJET), 3(5).

Yatich, S. A., \&Sakataka, W. (2016). Challenges Facing The Adoption Of Project Management Practices On Cdf Projects Success In Kapenguria Constituency, West Pokot County. 